\begin{tabular}{c} 
International Journal of Engineering \& Technology, $10(1)(2021) 14-22$ \\
International Journal of Engineering \& Technology \\
Website: www.sciencepubco.com/index.php/IJET \\
Research paper \\
\hline
\end{tabular}

\title{
Wood-steel composite shear walls with openings
}

\author{
Tzanetis Vogiatzis ${ }^{1 *}$, Themistoklis Tsalkatidis ${ }^{2}$, Aris Avdelas ${ }^{3}$ \\ ${ }^{1}$ Aristotle University of Thessaloniki \\ ${ }^{2}$ Norwegian University of Life Sciences \\ *Corresponding author E-mail: tzanetisvogiatzis@civil.auth,gr
}

\begin{abstract}
This paper reports an investigation into the behaviour of wood-steel composite shear walls, consisting of strand laminated lumber boundary frames with infill steel plates. Recently it has been shown that wood-steel composite shear wall systems can offer various advantages over code-approved wood frame shear walls, including architectural flexibility. However, further research is needed so as to gain a better insight and understanding into the structural behaviour of this lateral load resisting system. On this basis, three-dimensional full-scale finite element models are developed and used to simulate the wood-steel composite shear wall with solid infill plates and with centrallyperforated infill plates. In this paper, firstly, a three-dimensional finite element model of wood-steel composite shear wall under monotonic loading. The numerical results were compared with experimental data and it was found that the model can predict the behaviour of wood-steel composite shear walls with reasonable precision. Using the verified model, a parametric study on wood-steel composite shear wall models with and without openings was performed. Critical parameters influencing the wood-steel composite shear walls behaviour such as the thickness of the steel plate and the opening ratio were investigated. The results of this parametric study provide useful information for the engineering application of wood-steel composite shear wall systems.
\end{abstract}

Keywords: Steel-Timber Structures; Steel Plate Shear Walls; Wood-Steel Composite Shear Walls; Openings.

\section{Introduction}

A wood-steel composite shear wall (WSCSW) is a new-type lateral load resisting system, consisting of vertical steel plate infills connected to the surrounding engineered timber beams. The system could be a viable method of resisting lateral loads on buildings, such as wood-frame structures, which are particularly vulnerable to damage from loads caused by extreme winds and tornadoes. This is important e.g. in countries where wood-frame structures constitute most of the residential constructions [1]. The research on wood-steel composite shear walls started by specimens conceptually developed and cyclically tested by Conrad and Phillips [2]. Advantages include architectural flexibility for wall openings and open spaces in moderately sized residential and commercial buildings, due to their high shear strength per unit length, against equivalent wood light-framed shear walls.

The design for a wood-steel composite shear wall is similar to a steel plate shear wall (SPSW). A wide range of studies on SPSW systems has been conducted by many researchers [3-6], and design criteria are given by codes provided by the American Institute of Steel Construction - AISC-341 [7], and the Canadian Standards Association - CSA [8]. Following the SPSW design, a typical wood-steel composite shear wall comprises a steel infill plate that is allowed to buckle in shear and develop tension field action under lateral loading, while the engineered wood framing members remain essentially elastic. The connection at the interface between the infill plate and the boundary members is achieved through the use of structural epoxy. Hold-down assemblies are installed at the bottom corner of the woodsteel composite shear wall, to anchor it to its foundation. There are two different design philosophies with regard to base connection detailing. One approach employs elastic boundary conditions so that the steel infill plate can achieve high shear deformation. In contrast, the other employs inelastic boundary conditions in order to ensure that the value of wall over-strength is minimised. According to Conrad and Phillips [2], the failure modes recorded are column rupture for the former and hold-down rod fracture for the latter.

The engineered wood product used in [2], for the frame members of the wood-steel composite shear wall, was the commercially produced laminated strand lumber (LSL). Engineered wood products show good dimensional stability and structural characteristics compared to solid wood, while they can reduce the dependence on old-growth forests and high-quality logs, Moses and Prion [9]. Laminated strand lumber is one of the high-yield newly engineered wood products that show greater mechanical properties than solid lumber of the same species, as well as less variability, Moses et al. [10]. There is no generally accepted theory for the prediction of elastic and plastic stiffness and strength properties in wood [9], as it is for structural steel and concrete materials [11], [12]. The anisotropic nature of the wood in order to be simulated as an orthotropic material model requires a number of independent material properties which are difficult to measure and usually, they are not reported in the available publications. It is common among scholars to simplify the input values for radial and tangential direction, this can also be seen on the numerical modelling of hybrid steel framed with cross laminated timber infill shear walls - STSW [13], bolted hybrid connections [14], steel-timber composite floors [15], and hold-down connections for masstimber buildings [16]. 
A) With Solid Infill Plate

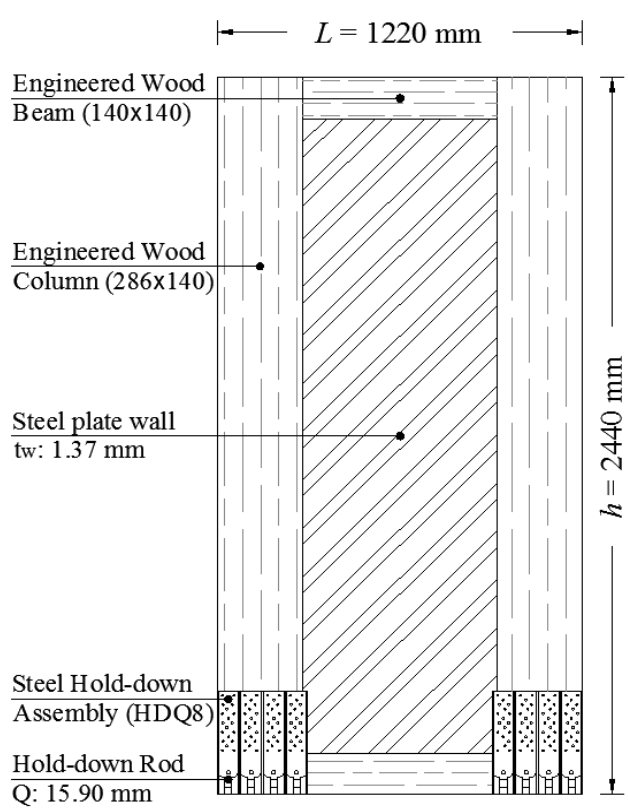

B) With Centrally-placed Opening

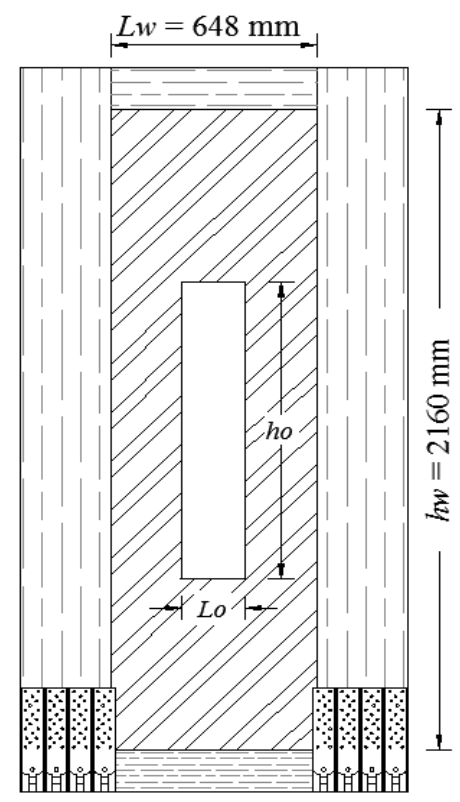

Fig. 1: Wood-Steel Composite Shear Walls - WSCSW.

From the available literature, it appears that although some reported experimental studies could be found in [2], very limited analytical or numerical investigation was reported on the behaviour of wood-steel composite shear wall systems. On this basis, it is necessary to undertake further comprehensive investigations in order to better understand the flexural behaviour of wood-steel composite shear wall systems. Thus, this paper conducts a necessary extension of the research on this issue.

\section{Methodology}

In order to study the behaviour of wood-steel composite shear walls with solid and perforated infill plates, a numerical model is developed and a parametric study is conceived. The varying parameters investigated are the plate thickness $\mathrm{t}_{\mathrm{w}}$ and the opening ratio $O$. Where the expression for the opening ratio is given by Equation 1, below

$O=\frac{L_{w} \cdot h_{w}}{L_{o} \cdot h_{p}}$.

The characteristics of the wood-steel composite shear wall models are shown in Table 1, in such a way that they can be identified from their labels. Details of those systems with a solid and with a centrally-perforated plate are shown in Figure 1a and Figure 1b, respectively.

Table 1: Characteristics of Solid and Perforated WSCSW Models

\begin{tabular}{llllll}
\hline FE Model & $\mathrm{t}_{\mathrm{w}}$ & $\mathrm{L}_{\mathrm{o}}$ & $\mathrm{h}_{\mathrm{o}}$ & $\mathrm{L}_{\mathrm{o}} \backslash \mathrm{L}_{\mathrm{w}}$ & $\mathrm{O}$ \\
\hline & $(\mathrm{mm})$ & $(\mathrm{cm})$ & $(\mathrm{cm})$ & & $(\%)$ \\
$\mathrm{W}_{-} \mathrm{t}_{\mathrm{w}}-\mathrm{L}_{\mathrm{o}} \mathrm{h}_{\mathrm{o}}$ & $1.37,2.0,2.5,3.0,3.5,4.0$ & 20 & $50,100,150$ & $1 / 3$ & $0.7,14,21$ \\
\hline
\end{tabular}

\subsection{Design considerations}

The design of the wood-steel composite shear wall was based on the guidelines provided for SPSWs within the AISC [17]. Following this guide an infill plate thickness of $1.37 \mathrm{~mm}$ was used for the $1220 \mathrm{~mm} \times 2440 \mathrm{~mm}$ wood-steel composite shear wall. The shear strength $\mathrm{V}_{\mathrm{p}}$ was calculated as $161.80 \mathrm{kN}$, according to Equation 2 provided by Berman and Bruneau [18]. Here, $\mathrm{F}_{\mathrm{y}}$ is the steel infill plate yield stress, $t_{w}$ is the thickness of the infill plate, $L_{w}$ is the bay width, and $\alpha$ is the inclination angle of the tension field

$\mathrm{V}_{p}=\frac{1}{2} \cdot F_{y} \cdot t_{w} \cdot L_{w} \cdot \sin 2 a$

The angle of diagonal tension field $\alpha$ was calculated as $30.50^{\circ}$ according to Equation 3, given by Timler and Kulak [19], where: $\mathrm{A}_{\mathrm{c}}$ is the cross-sectional area of the vertical boundary elements, $A_{b}$ is the cross-sectional area of the horizontal boundary elements, and $I_{c}$ is the moment of inertia of the vertical boundary elements. With the angle of the tension field known, boundary beams, $140 \times 140(\mathrm{~mm})$, and boundary columns, $286 \times 140(\mathrm{~mm})$, were selected

$$
\alpha=\tan ^{-1} \sqrt{\frac{1+\frac{t_{w} \cdot L_{w}}{2 \cdot A_{c}}}{1+t_{w} \cdot h \cdot\left(\frac{1}{A_{b}}+\frac{h_{w}^{3}}{360 \cdot l_{c} \cdot L}\right)}}
$$


A) With Solid Infill Plate

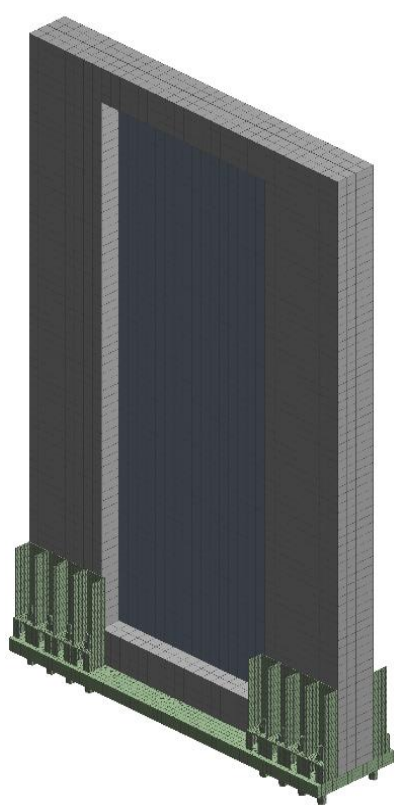

B) With Centrally-placed Opening

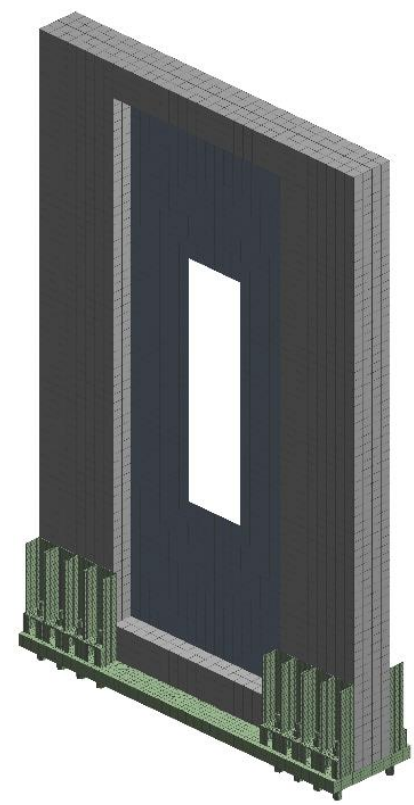

Fig. 2: Generated Finite Element Models.

\subsection{Finite element analysis}

\subsubsection{General descriptions}

Three-dimensional finite element models are established to predict the nonlinear behaviour of wood-steel composite shear wall systems under monotonic loading. The commercially available finite element software ANSYS [20], is used throughout the finite element analysis, accounting for geometrical and material nonlinearity. The boundary conditions and target drift are in accordance with typical tests. The loading process was controlled by displacement at the top beam, so as to improve the rate of convergence and to prevent numerical instabilities. The interface between the boundary frame members and the infill plate was assumed to have a perfect bond condition. An initial imperfection corresponding to the first mode of buckling $\mathrm{h}_{\mathrm{w}} / 1000$, is applied to aid the initiation of elastic buckling and the development of tension fields with reference to the guidelines provided by the American Society of Civil Engineers - ASCE [21]. Due to the nonlinear nature of the modelling used, the well-known Newton-Raphson incremental iterative solution method was used in the analysis.

\subsubsection{Material modelling}

A typical wood-steel composite shear wall generally consists of boundary frame beams and columns, along with the infill plate, the holddown brackets and the hold-down rods. All these components are constructed by using the twenty-node structural brick element SOLID 186 with three translational and three rotational degrees of freedom at each node. The generated mesh used for the analysis of the woodsteel composite shear wall with solid and with centrally-perforated plate are respectively depicted in Figure 2a and Figure $2 \mathrm{~b}$.

The trilinear stress - strain relation developed by Tao et al. [22], is adopted in order to model the steel material for the infill plate. As it can be seen from Equation 4, the three parameters needed to determine the full-range stress-strain curve are the elastic modulus $\left(\mathrm{E}_{\mathrm{s}}\right)$, the yield strength $\mathrm{f}_{\mathrm{y}}$ and the ultimate strength $\mathrm{f}_{\mathrm{u}}$. The rest of the parameters of the equation are computed with formulas provided in [22]

$\sigma_{s}=f_{y}+E_{h} \cdot\left(\varepsilon_{s}-\varepsilon_{s h}\right) \cdot\left(1-E_{s h} \cdot \frac{\varepsilon_{s}-\varepsilon_{s h}}{4 \cdot\left(f_{s u}-f_{s y}\right)}\right)$.

A bilinear stress-strain relationship is used for the steel hold-down brackets and the $\varnothing 15.9$ hold-down rods, with a tangent modulus $\mathrm{E}_{\mathrm{t}}$ equal to $0.01 \mathrm{E}_{\mathrm{s}}$. In Conrad and Phillips [2], material properties are provided for the infill plate and the Ø15.9 hold-down rods, but not for the Simpson Strong-Tie HDQ8 hold-down brackets, which are characterised as 7 ga. in Simpson [23]. Hence, the material yield limit for the hold-down brackets is assumed to be $235 \mathrm{MPa}$, within the range of galvanised steel sheets minimum $30,000 \mathrm{psi}(\approx 207 \mathrm{MPa})-$ $55,000 \mathrm{psi}(\approx 379 \mathrm{MPa})$. The adopted material mechanical properties for the steel members of the finite element model are given in Table 2. For all simulated steel members, the Poisson's ratio $v$ is taken as 0.3 .

Table 2: Mechanical Properties of Steel Members Used in the FE Models

\begin{tabular}{llll}
\hline Member & $\mathrm{E}_{\mathrm{s}}$ & $\mathrm{f}_{\mathrm{y}}$ & $\mathrm{f}_{\mathrm{u}}$ \\
\hline & $(\mathrm{MPa})$ & $(\mathrm{MPa})$ & $(\mathrm{MPa})$ \\
Infill plate & 210,000 & 415 & 567 \\
Hold-down brackets & 210,000 & 236 & 360 \\
$\varnothing 15.9$ Hold-down rods & 210,000 & 316 & 454 \\
\hline
\end{tabular}


The laminated strand lumber orthotropic elastic and plastic performance for the boundary frame members, is simulated by enabling within ANSYS the anisotropic elasticity capability, the Hill plasticity model and the bi-linear kinematic hardening law. Previous finite element analyses conducted by He et al. [24] have demonstrated the adequacy of the generalized Hill model for capturing the behaviour of engineered wood materials.

The values for the longitudinal elastic modulus $\mathrm{E}_{\mathrm{L}}$, along with the axial tensile strength $\sigma_{\mathrm{t}}$, the axial compressive strength $\sigma_{\mathrm{c}}$, the perpendicular to grain compressive strength $\sigma_{c, \perp}$, and the shear strength $\tau_{\mathrm{v}}$, were obtained from the Weyerhaeuser [25], evaluation report, with respect to the orientation and load direction of each frame member (joist/beam for columns and face/plank for beams). The parameters for the transverse elastic modulus $\mathrm{E}_{\mathrm{T}}$, along with the shear moduli for the longitudinal $\mathrm{G}_{\mathrm{L}}$ and transverse $\mathrm{G}_{\mathrm{T}}$ direction were obtained, corresponding to stress grade $\mathrm{E}_{\mathrm{L}}$ from a sensitivity study conducted on the properties given in Moses and Prion [9], Moses et al. [10], Wang et al. [26], for laminated strand lumber. It was found that, for the transverse elastic modulus $\mathrm{E}_{\mathrm{T}}=\mathrm{E}_{\mathrm{L}} \backslash 10$, similar to Wang et al. [26], and for the shear moduli $\mathrm{G}_{\mathrm{L}}=\mathrm{E}_{\mathrm{L}} \backslash 36$, and $\mathrm{G}_{\mathrm{T}}=\mathrm{E}_{\mathrm{L}} \mathrm{x}(2 \backslash 7)$, as in Moses et al. [10]. The Poisson's ratio used in the analysis for the laminated strand lumber is obtained with reference to [10], and according to the model criterion presented in Equation 5.

$1-2\left(v_{x y} \frac{E_{x}}{E_{y}}-v_{y z} \frac{E_{y}}{E_{z}}-v_{x z} \frac{E_{x}}{E_{z}}-v_{x y} v_{x z} \frac{E_{x}}{E_{z}}\right) \geq 0$

The input for the laminated strand lumber elastic properties and strengths adopted in the developed numerical model are given in Table 3.

Table 3: Mechanical Properties of Laminated Strand Lumber Members Used in the FE Models

\begin{tabular}{|c|c|c|c|c|c|c|c|c|c|c|}
\hline Orientation & $\begin{array}{l}\mathrm{E}_{\mathrm{L}} \\
(\mathrm{MPa})\end{array}$ & $\begin{array}{l}\mathrm{E}_{\mathrm{T}} \\
(\mathrm{MPa})\end{array}$ & $\begin{array}{l}\mathrm{G}_{\mathrm{L}} \\
(\mathrm{MPa})\end{array}$ & $\begin{array}{l}\mathrm{G}_{\mathrm{T}} \\
(\mathrm{MPa})\end{array}$ & $\begin{array}{l}\mathrm{VL}_{\mathrm{L}} \\
(\mathrm{MPa})\end{array}$ & $\begin{array}{l}\text { VT } \\
(\mathrm{MPa})\end{array}$ & $\begin{array}{l}\sigma_{\mathrm{t}} \\
(\mathrm{MPa})\end{array}$ & $\begin{array}{l}\sigma_{\mathrm{c}} \\
(\mathrm{MPa})\end{array}$ & $\begin{array}{l}\sigma_{\mathrm{c}, \perp} \\
(\mathrm{MPa})\end{array}$ & $\begin{array}{l}\tau_{\mathrm{v}} \\
(\mathrm{MPa})\end{array}$ \\
\hline Joist/beam & 11,024 & 1102 & 394 & 169 & 0.042 & 0.0022 & 14.19 & 15.40 & 6.44 & 3.76 \\
\hline Face/plank & 11,024 & 1102 & 394 & 169 & 0.042 & 0.0022 & 14.19 & 15.40 & 5.55 & 1.03 \\
\hline
\end{tabular}

\section{Numerical results}

The accuracy of the finite element analysis (FEA) is verified by comparing the numerical predictions with the results obtained from the tests conducted by Conrad and Phillips [2]. The numerical and experimental results are presented in Figure 3 in terms of lateral load $\mathrm{P}$ versus total drift $\theta$ curves, and tabulated in Table 4 in terms of strength $P_{v}$, displacement $D$ at $P_{v}$, and stiffness $E_{m}$. Moreover, the stress distribution of the wood-steel composite shear wall is given in Figure 4a. The results of the developed finite element model W-1.37-0/0, show a fairly good concurrence with the experimental ones, which is indicative of the validity and accuracy of the numerical simulations.

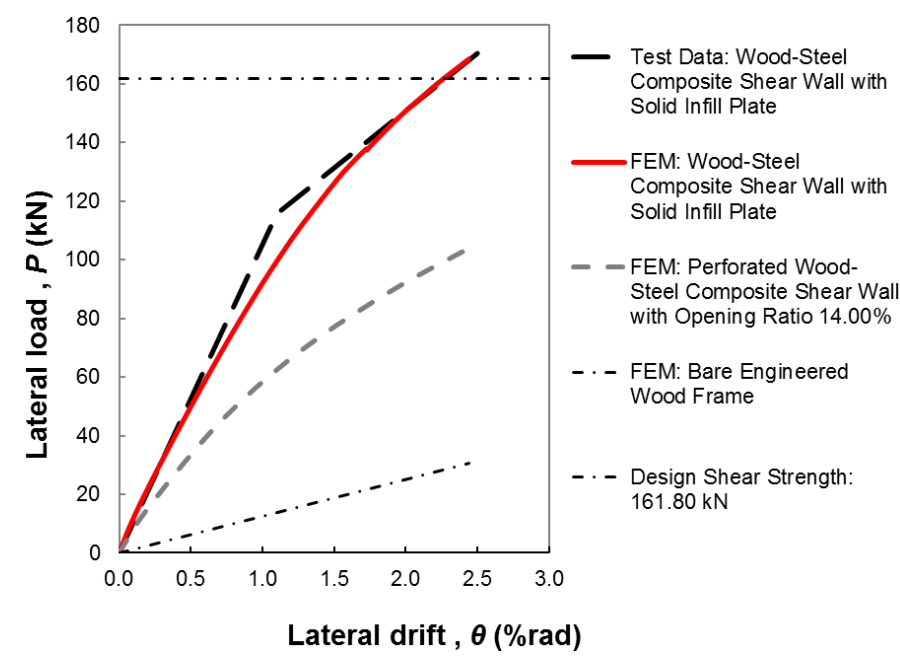

Fig. 3: Lateral Load - Total Drift Numerical Results of the WSCSW System.

The effect of the steel infill plate in the lateral response of the wood-steel composite shear wall can be also seen at Figure 4 as the numerical results generated for the bare engineered wood frame are also included. Within the comparison graph the data from a perforated wood-steel composite shear wall with opening ratio 14.00\%, along with designed shear strength as computed in [2], are also included.

Table 4: Comparison of Numerical Predictions and Experimental Results

\begin{tabular}{llll}
\hline Criterion & Test & FEA & FEA/Test \\
\hline $\mathrm{P}_{\mathrm{v}}(\mathrm{kN})$ & 170.40 & 168.31 & 0.99 \\
$\mathrm{D}(\mathrm{mm})$ & 60.96 & 61.00 & 1.00 \\
$\mathrm{E}_{\mathrm{m}}(\mathrm{MPa})$ & 4313 & 4062 & 0.94 \\
\hline
\end{tabular}




\section{Parametrical study}

\subsection{Opening ratio}

In this section, the effect of centrally located rectangular openings on the response of wood-steel composite shear walls is explored. To this end, finite element models with opening ratios $O$ equal to $0.7 \%, 14 \%$, and $21 \%$ are evaluated. Typical results obtained from this study are shown in Figure 3 and Figure 4 for the wood-steel composite shear wall models with centrally-placed openings and $1.37 \mathrm{~mm}$ plate thickness. The obtained results from the generated finite element models are compared to the wood-steel composite shear wall model with a solid infill plate. The horizontal line in the plotted lateral load P versus total drift $\theta$ curves in Figure 3 marks the designed shear strength $\mathrm{Vp}$, and the dotted line in the figure marks the P- $\theta$ curve of the bare frame. Comparison with the bare frame results shows that the solid infill plate contributes about $80 \%$ of the total WSCSW shear strength.

Figure 4 shows the impact of the opening ratio on the von-Mises stress distribution results at a $2.50 \%$ target drift $(\approx 61 \mathrm{~mm}$ displacement), for the wood-steel composite shear wall models with a solid plate and with a centrally-perforated infill plate. From Figures $4 \mathrm{a}$ to $4 \mathrm{~d}$, it becomes evident that introduction of openings, in these lateral-load resisting systems, can reduce the shear capacity by lowering the contribution of the infill plate and consequently, adversely affecting the system by increasing the demand on the boundary frame members.

The stiffness and strength of wood-steel composite shear walls as a function of the opening area ratio $O$ are plotted in Figures $5 \mathrm{a}$ and $6 \mathrm{a}$, respectively. It can be observed that the stiffness and strength of wood-steel composite shear walls decreased drastically due to the presence of the centrally-placed opening. Also, the rate of decrease slows down as the opening size increases. More specifically, while the opening area ration ascends from $0 \%$ to $21 \%$, the stiffness and shear strength are both descending at approximately $50 \%$, for wood-steel composite shear walls. From the results presented in Figure 5b, it is clear that a parabolic relationship can describe the stiffness and strength ratio as a function of the opening ratio, for wood-steel composite shear walls with centrally-placed openings.

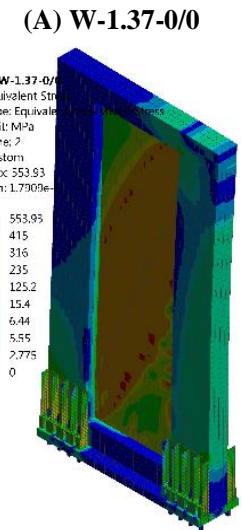

(E) W-2.50-0/0

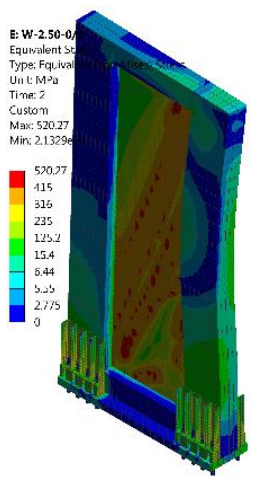

(I) $\mathrm{W}-3.50-0 / 0$

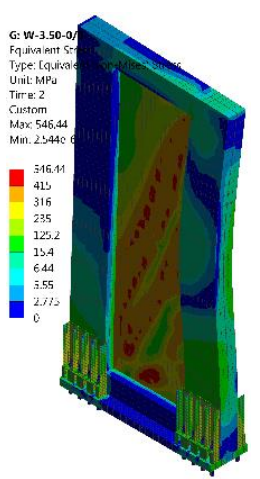

(B) $\mathrm{W}-\mathbf{1 . 3 7 - 2 0 / 5 0}$

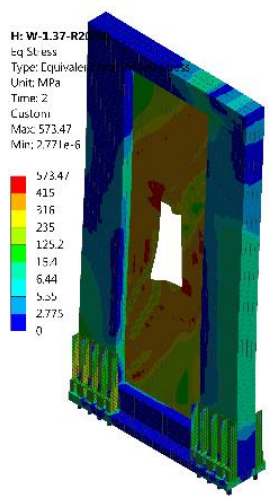

(F) W-2.50-20/50

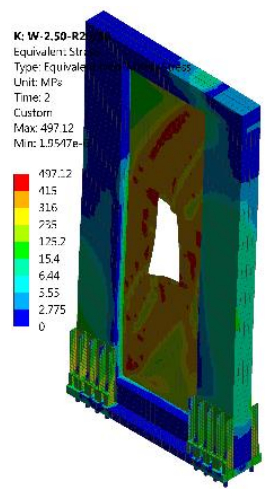

(J) W-3.50-20/50

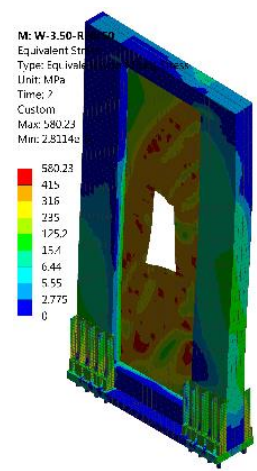

(C) W-1.37-20/100

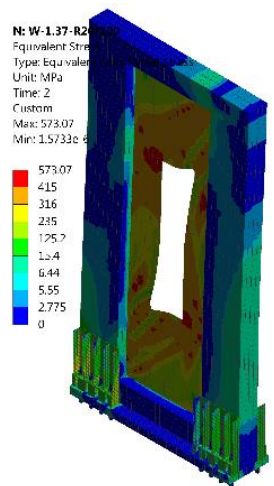

(G) W-2.50-20/100

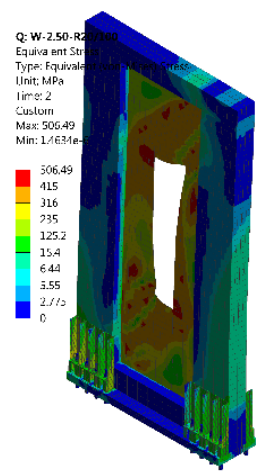

(K) W-3.50-20/100

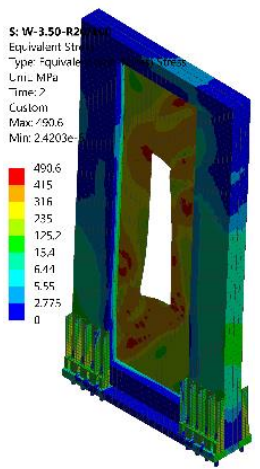

(D) $\mathrm{W}-1.37-20 / 150$

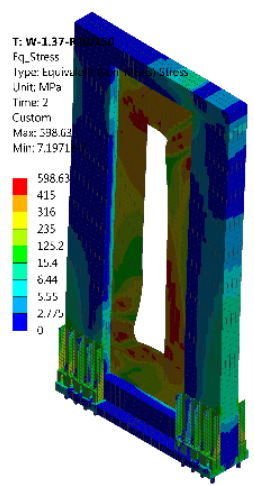

(H) W-2.50-20/150

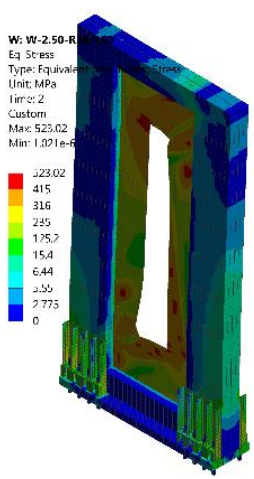

(L) W-3.50-20/150

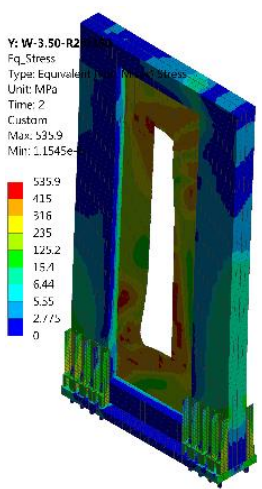

Fig. 4: Von-Mises Stress Results at 2.50\% Drift for the Wood-Steel Composite Shear Wall Models. 
(A)

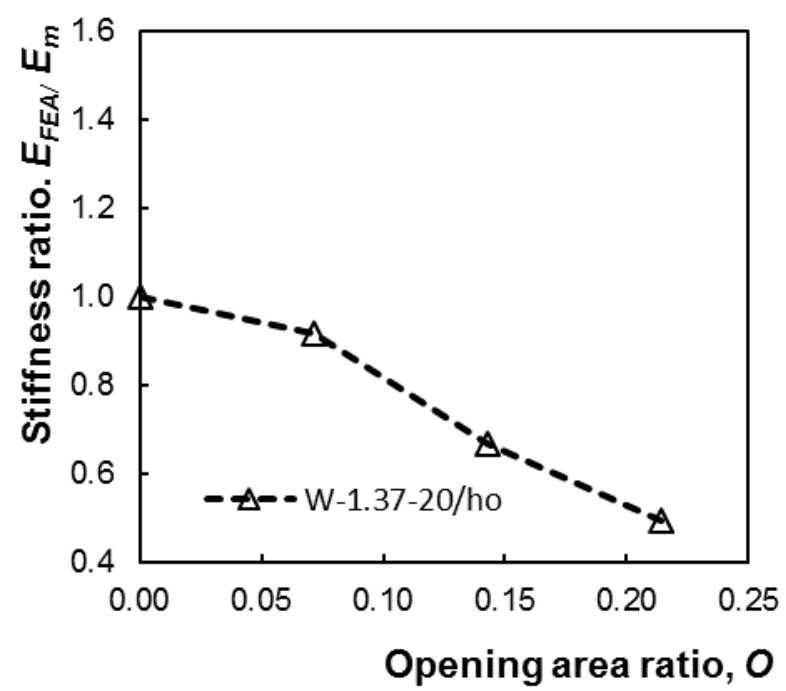

(C)

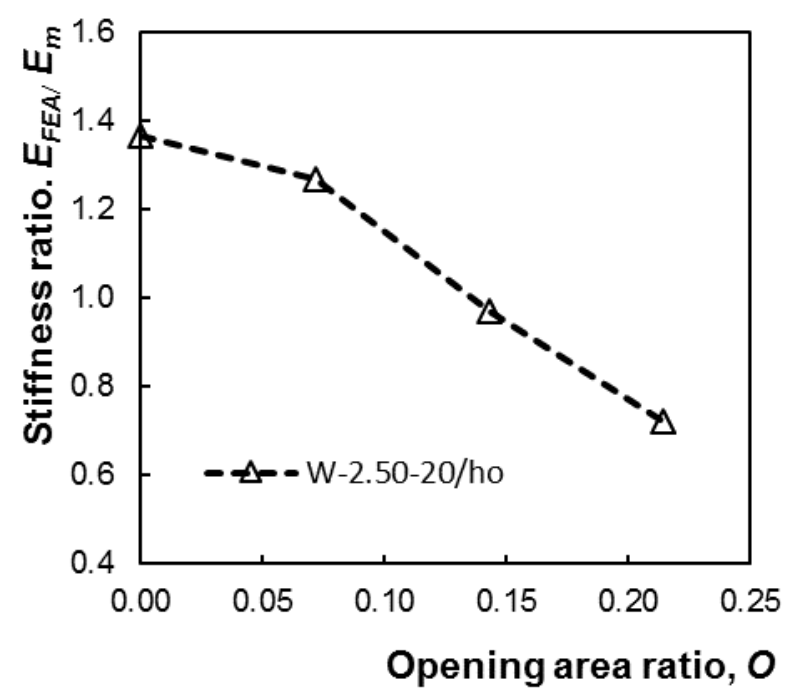

(E)

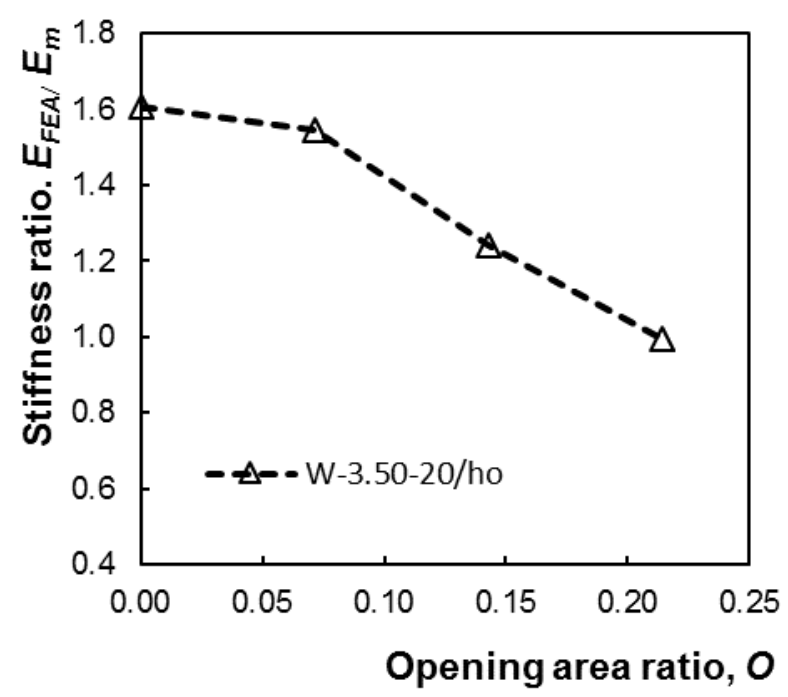

(B)

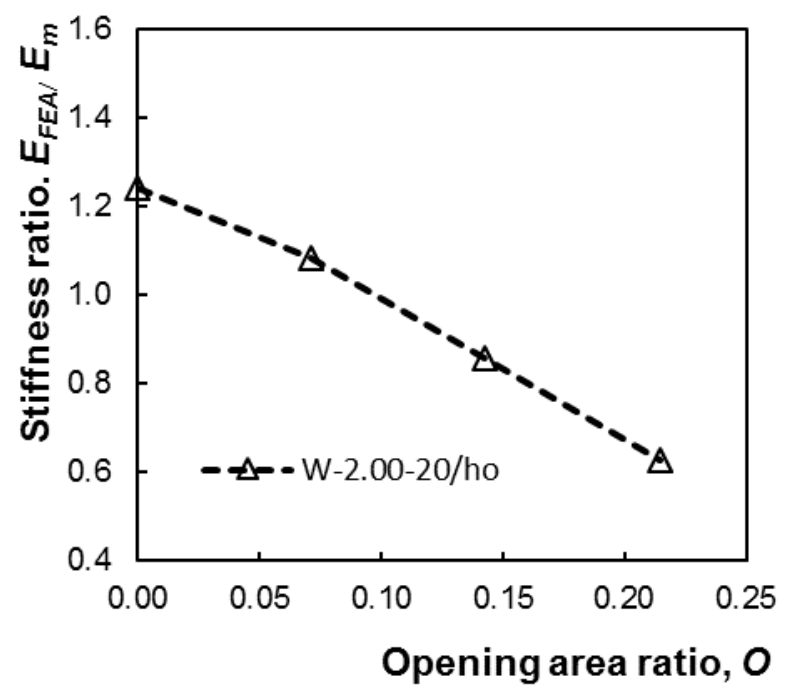

(D)

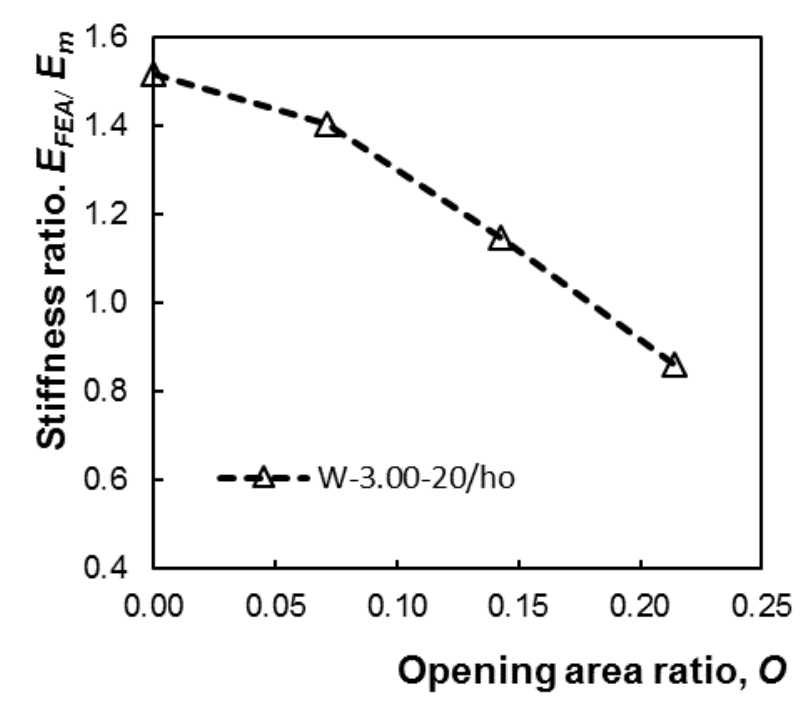

(F)

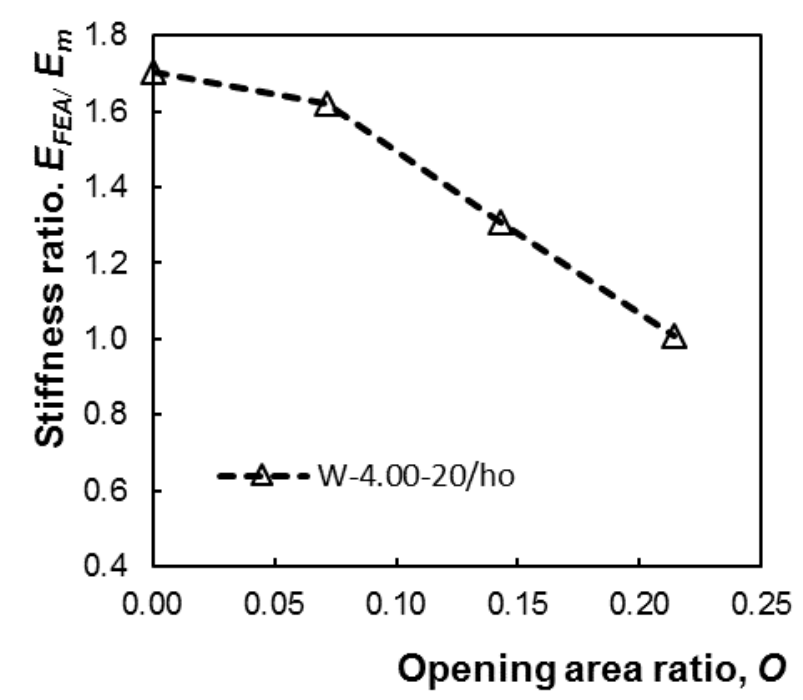

Fig. 5: The effect of opening ratio on the stiffness of wood-steel composite shear wall models. 
(A)

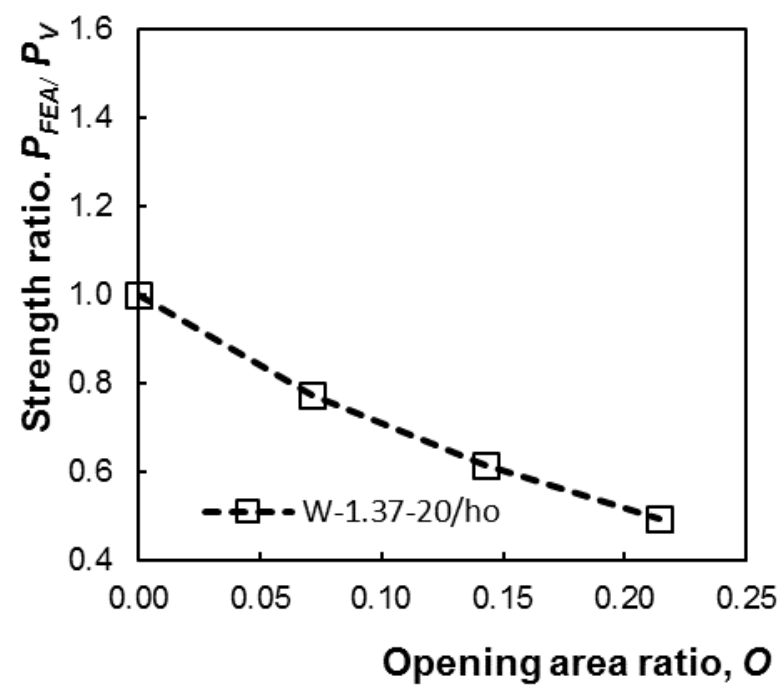

(C)

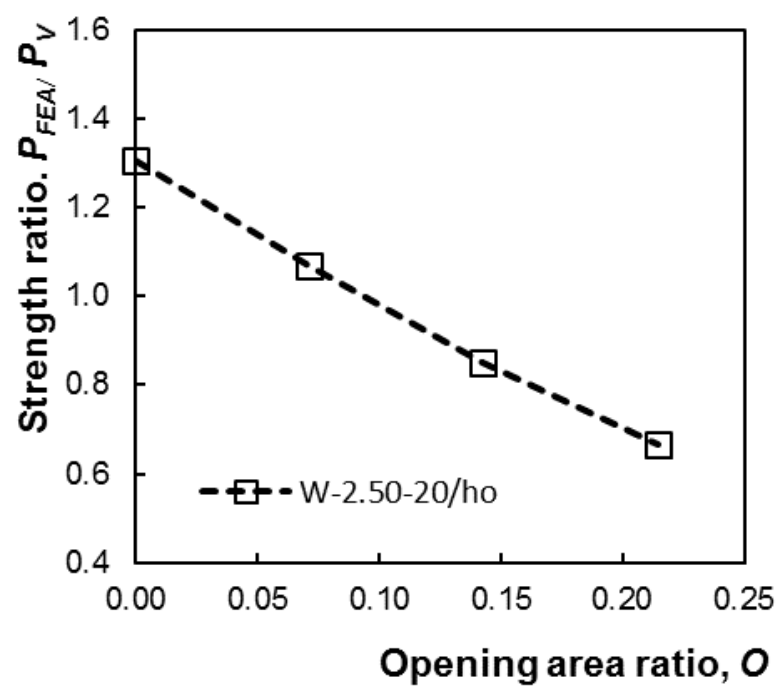

(E)

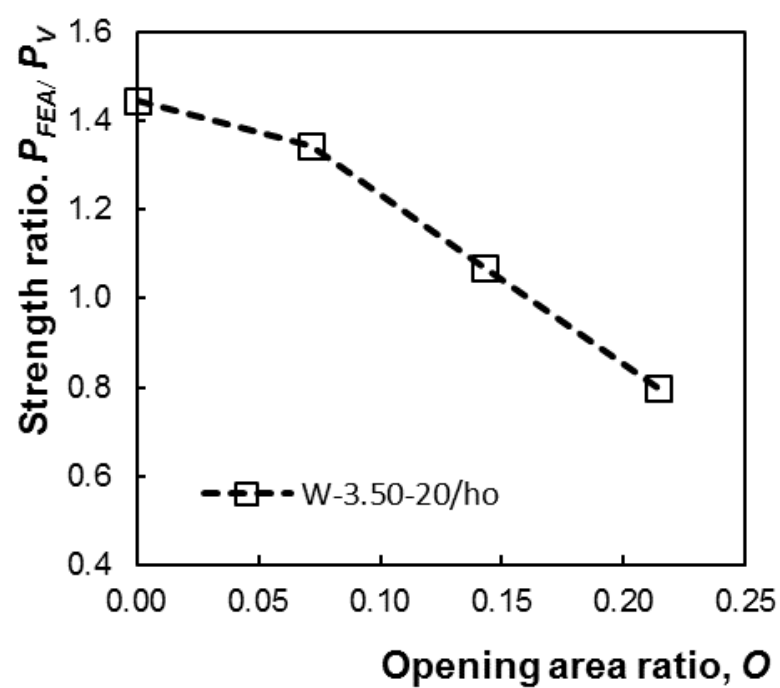

(B)

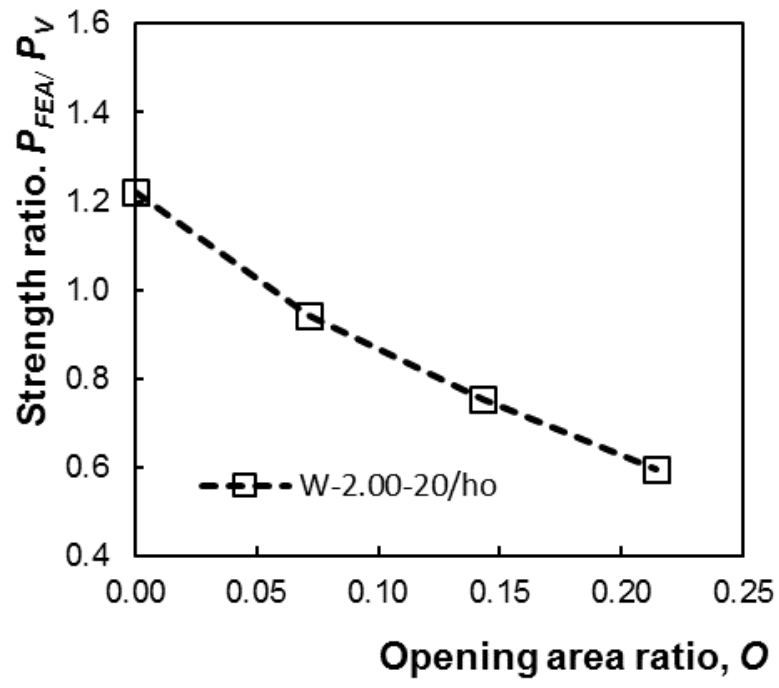

(D)

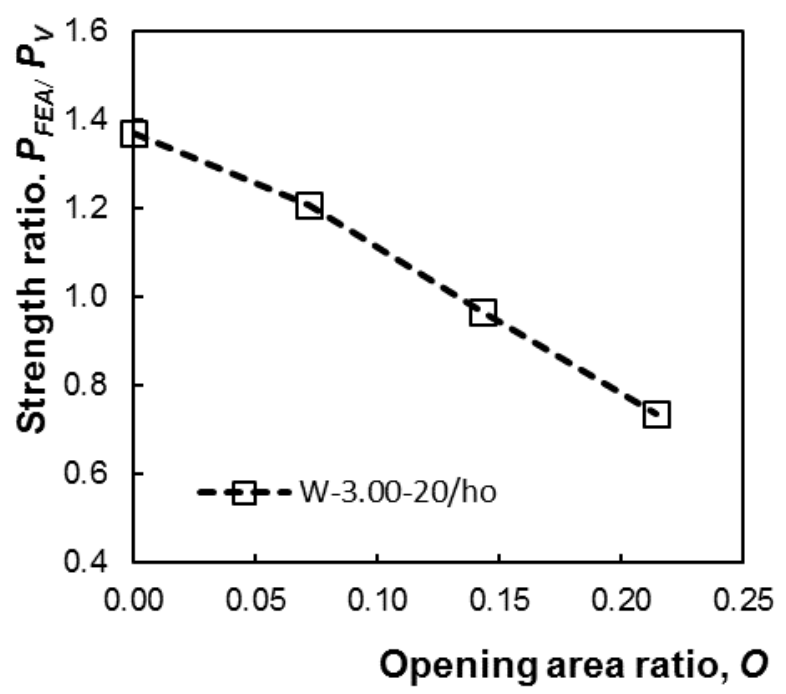

(F)

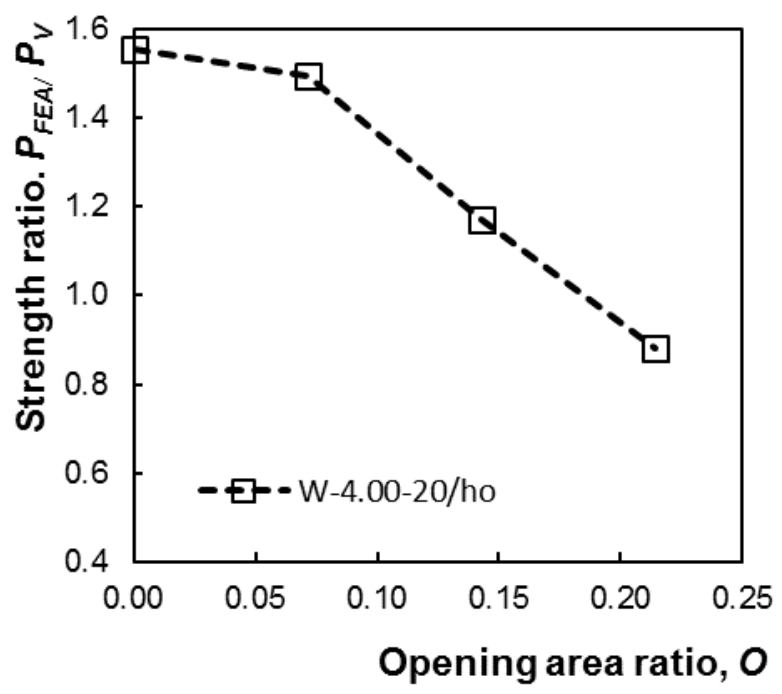

Fig. 6: The effect of opening ratio on the strength of wood-steel composite shear wall models. 


\subsection{Infill plate thickness}

In this section, the effect of the infill plate thickness on the behaviour of wood-steel composite shear walls with a solid and with a centrally-perforated infill plate is investigated. To this end, several finite element models with infill plate thickness equal to $t_{w}=1.37,2,3$, $3.5,4$ and with centrally-placed opening area ratio equal to $O=0.7 \%, 14 \%$, and $21 \%$ are evaluated. Typical von-Mises stress distribution results, for the wood-steel composite shear wall models with a solid plate and with a centrally-perforated infill plate, are presented in Figure 4, at a $2.50 \%$ target drift. Figures 5 and 6 show the impact of the opening ratio on the response of the wood-steel composite shear wall models for various infill wall thickness values. From the results it becomes evident that an ascent on infill plate thickness can increase the shear capacity of wood-steel composite shear wall models with a solid plate and with a centrally-perforated infill plate.

The obtained results from the generated finite element models are plotted in Figure 3, for wood-steel composite shear wall models with a solid plate and with a centrally-perforated infill plate. The horizontal line in the plotted lateral load P versus total drift $\theta$ curves plotted in Figure 3 mark the designed shear strength $\mathrm{V}_{\mathrm{p}}$, and the dotted line in the figure mark the P- $\theta$ curve of the bare frame. The stiffness and strength of wood-steel composite shear walls as a function of the plate thickness $t_{w}$ is plotted in Figure 7 . The plate thickness ratio is given from the expressions $1.37 \backslash \mathrm{t}_{\mathrm{w}}$. The findings of this study show that an ascent on the infill plate thickness from 1.37 to $4.0 \mathrm{~mm}$ can increase the shear capacity up to $60 \%$ for wood-steel composite shear walls with solid infill plate, and up to $70 \%$ for wood-steel composite shear walls with opening area ratio $O=14 \%$. Further, it is observed that the highest increase on strength is about $20 \%$ and noted for a solid infill plate Figure $6 \mathrm{a}$ and for a centrally-perforated plate Figure 6b, from 1.37 to $2.00 \mathrm{~mm}$.

(A)

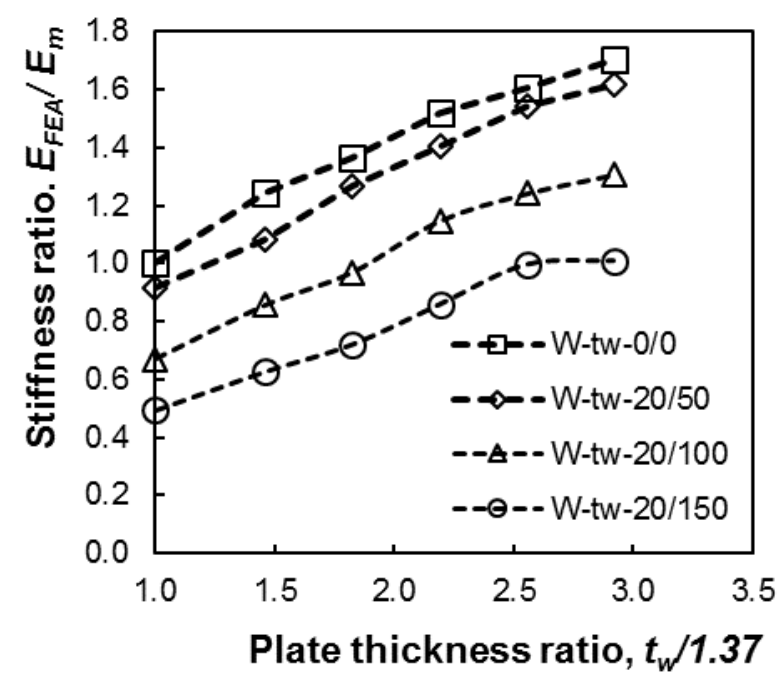

(B)

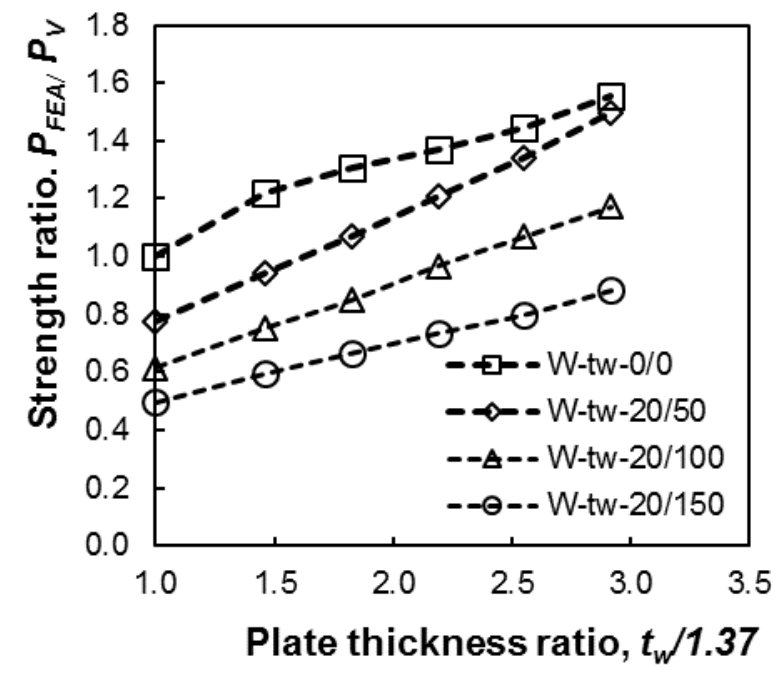

Fig. 7: The effect of plate thickness on wood-steel composite shear walls with and without opening.

\section{Discussion and conclusions}

In the first part of this work, a detailed three-dimensional finite element model was developed in order to study the nonlinear behaviour of wood-steel composite shear wall systems under monotonic loading. The numerical model was simulated with laminated strand lumber (Table 3) boundary frame members, and was constructed in such a manner as to facilitate further parametric analyses. The numerical response of the developed wood-steel composite shear wall model has been reported in Figure 3 along with other curves related to a timber bare frame from laminated strand lumber, and a perforated wood-steel composite shear wall system with an opening ratio of $14.00 \%$.

It was found that the generated numerical model (Figure 1a and Figure 2a) can adequately capture and predict the response of wood-steel composite shear wall systems (Figure 3). A good correlation between the numerical predictions and the experimental results was found according to the correlation factors presented in Table 4 for the strength, the displacement and the stiffness with values equal to 0.99 , 1.00 and 0.94 , respectively. The presence of the steel plate infill alters significantly the performance of the bare engineered wood frame, by improving not only the lateral stiffness, but also the load capacity. The impact of this alteration is graphically observed within Figure 4.

Using the developed numerical model, a parametrical study was conducted in the second part of this work. A number of wood-steel composite shear wall models were numerically analyzed in order to evaluate the effectiveness of both centrally located openings and infill thickness, on the response of this lateral load resisting system. To this end, a number of wood-steel composite shear wall models with centrally located rectangular openings was conceptually developed (Figure $1 \mathrm{~b}$ and $2 \mathrm{~b}$ ), for various opening ratios and infill plate thickness values, according to Table 1 . The combined effect of those two parameters on the behaviour of wood-steel composite shear walls is illustrated at the numerical von-Mises stress distribution results given in Figure 4. Moreover, the stiffness and strength results are given, initially as a function of the opening area ratio (Figure 5 and Figure 6), and in the following as a function of the plate thickness (Figure 7).

It was found that the introduction of centrally-located openings can reduce the shear capacity and adversely affect the response of woodsteel composite shear walls. It was also demonstrated that increasing the opening size is directly related with the decreasing of stiffness and strength of the system and parabolic relationships were obtained between these two quantities. Results are indicative that by increasing the opening size within the infill plate, the boundary frame members receive most of the shear capacity demand of the wood-steel composite shear walls. The results presented in Figures $7 \mathrm{a}$ and $7 \mathrm{~b}$ are indicative that a linear relationship can describe the increase in 
stiffness and strength as a function of thicker infill plates, for wood-steel composite shear walls with and without openings. Also, findings of this study reveal the effectiveness of using a proper infill plate thickness in order to improve the stiffness and strength of woodsteel composite shear walls with a centrally-placed opening.

\section{Author contributions}

TV, TT and AA visualized the problem and conceived the study. TV and TT were responsible for the design and development of the data analysis. TV was responsible for the data collection and wrote the first draft of the article. TT and AA review and edited the first draft. $\mathrm{TV}, \mathrm{TT}$ and AA were responsible for data interpretation and the final form of the article.

\section{Disclosure statement}

The authors declare that they do not have any competing financial, professional, or personal interests from other parties in the subject matter discussed in this manuscript.

\section{References}

[1] Quayyum S., "Parametric models for wind load resistance of wood-frame walls". Engineering Structures, Vol. 183, pp 841-859, 2019. https://doi.org/10.1016/j.engstruct.2019.01.058

[2] Conrad K. and Phillips A.R., "Full scale development of wood-steel composite shear walls", Structures, 20, 268-278, 2019. https://doi.org/10.1016/j.istruc.2019.04.010

[3] Caccese V., Elgaaly M., Chen R., "Experimental study of thin steel-plate shear walls under cyclic load", J Struct Eng., Vol. 136, pp 665-675, 1993. https://doi.org/10.1061/(ASCE)0733-9445(1993)119:2(573)

[4] Driver R.G., Kulak G.L., Kennedy D.L., Elwi, A.E., "Cyclic test of four-story steel plate shear wall”, J Struct Eng., Vol. 124, Issue 2, 1998 https://doi.org/10.1061/(ASCE)0733-9445(1998)124:2(112) 629-67

[5] Berman J.W. and Bruneau, M., "Experimental investigation of light-gauge steel plate shear walls". J Struct Eng., Vol. 131, Issue 2, pp 259-67, 2005. https://doi.org/10.1061/(ASCE)0733-9445(2005)131:2(259)

[6] Zirakian T., and Zhang J., "Structural performance of unstiffened low yield point steel plate shear walls", J Struct Eng., Vol. 112, pp 40-53, 2015. https://doi.org/10.1016/j.jcsr.2015.04.023

[7] American Institute of Steel Construction, Seismic Provisions for Structural Steel Buildings - AISC 341-10, Chicago, U.S.A., 2010.

[8] Canadian Standards Association - CSA, Design of Steel Structures - CSA. S16-14, Canada, 2014.

[9] Moses D.M. and Prion H.G.L., "Stress and failure analysis of wood composites: a new model", Compos. B Eng., Vol. 35, pp 251-261, 2004. https://doi.org/10.1016/j.compositesb.2003.10.002

[10] Moses D.M., Prion H.G.L., Li H., et al., "Composite behavior of laminated strand lumber”, Wood Sci Technol, Vol. 37, Issue 1, pp 59-77, 2003. https://doi.org/10.1007/s00226-003-0169-5

[11] Vogiatzis T., Avdelas A., Tsalkatidis T., "The Composite Interaction Effect in SRCWs with Semi-Rigid Connections”, ASCE 2016 Engineering Mechanics Institute International Conference, France, October 25-27, A10278, 2016.

[12] Vogiatzis T., and Avdelas, A., "Study of composite steel frame with reinforced-concrete infill", Structures and Buildings, Vol. 171, Issue SB2, pp 178-192, 2018. https://doi.org/10.1680/jstbu.16.00192

[13] Vogiatzis T., Tsalkatidis T., Avdelas A., "Steel framed structures with cross-laminated timber infill shear walls and semi-rigid connections", International Journal of Engineering and Technology, Vol. 8, Issue 4, pp 433-443, 2019. https://doi: 10.14419/ijet.v8i4.29742

[14] Tsalkatidis T., Amara Y., Embaye S., Nathan E., "Numerical Investigation of Bolted Hybrid Steel-timber Connections", Frontiers in built environment, Vol. 4, Article 48, 2018. https://doi.org/10.3389/fbuil.2018.00048

[15] Hassanieh A., Valipour H.R., Bradford M.A., "Experimental study of steel-timber composite (STC) beams". Journal of Constructional Steel Research, Vol. 122, pp 367-378, 2016., https://doi.org/10.1016/j.jcsr.2016.04.005

[16] Mpidi Bita H., and Tannert T., (2018)., "Numerical optimization of novel connection for cross-laminated timber buildings", Engineering Structures, 175, 273-283. https://doi.org/10.1016/j.engstruct.2018.08.020

[17] Sabelli R. and Bruneau M., "Steel plate shear walls. Design guide 20", AISC, Chicago, IL, U.S.A., 2007.

[18] Berman, J.W. and Bruneau M., "Plastic analysis of steel plate shear walls", J Struct Eng., Vol. 129, Issue 11, pp 1448-56, 2003 https://doi.org/10.1061/(ASCE)0733-9445(2005)131:2(259)

[19] Timler, O.A. and Kulak G.L., Experimental Study of Steel Plate Shear Walls - Structural Engineering Report no 114, University of Alberta, Edmonton, Canada, 1983.

[20] ANSYS, ANSYS Mechanical APDL User's manual @ANSYS, 2015.

[21] ASCE, SEI/ASCE 7-10, . Minimum design loads for buildings and other structures, Virginia, U.S.A., 2010.

[22] Tao Z., Wang X., Uy B., "Stress-strain curves of structural and reinforcing steel after exposure to elevated temperatures", Journal of Materials in Civil Engineering ASCE, Vol. 25, Issue 9, pp 1306-1319, 2013. https://doi.org/10.1061/(ASCE)MT.1943-5533.0000676

[23] Simpson Strong-Tie Company INC, Wood Construction Connectors, Canadian Limit States Design. Catalogue C-C-CAN2015, 2015.

[24] He M., Sum X., Li Z., "Bending and compressive properties to cross-laminated timber (CLT) panels made from Canadian hemlock", Construction and Building Materials, Vol. 185, pp 175-183, 2018. https://doi.org/10.1016/j.conbuildmat.2018.07.072

[25] Weyerhaeuser, Structural composite lumber and oriented strand board: Timber strand laminated strand lumber (LSL), Evaluation report ESR1387 ICC-ES, 2018

[26] Wang Z., Gong M., Chui Y.H., "Mechanical properties of laminated strand lumber and hybrid cross-laminated timber", Construction and Building Materials, Vol. 101, pp 622-627, 2015. https://doi.org/10.1016/j.conbuildmat.2015.10.035 